\title{
The Influence of International Civic and Citizenship Studies on Education in Chile
}

\author{
Gabriela Cares Osorio and Elisa Salinas Valdivieso $0^{1,2}$
}

\begin{abstract}
This chapter addresses the participation of Chile in IEA's Civic Education Study (CIVED), International Civic and Citizenship Education Study (ICCS) 2009, and ICCS 2016. Participation in these civic studies has influenced civic education in the country in different ways. First, it contributed to educational discourse by providing relevant evidence on students' knowledge and attitudes. Second, it served as an input that triggered curricular revisions and modifications in the last 20 years. Third, it shaped a research community in the field. Key to these contributions have been both the results of the studies and their assessment frameworks. These elements set a common language in educational discourse and provided evidence that serves as a foundation for further discussions.
\end{abstract}

\section{Introduction}

Chile has a long tradition assessing students' achievements. In the last two decades, together with well-established national programs of evaluation, the country participated in several international assessments of student achievement including the International Association for the Evaluation of Educational Achievement's (IEA) TIMSS, CIVED, and ICCS, ${ }^{3}$ and the Organisation for Economic Co-operation and Development's (OECD) PISA. ${ }^{4}$ The decision to join an international study is centrally taken by the National Council of Education, based on a proposal presented by the Ministry of Education. Once approved, the participation of the country in each project is included in a medium-term strategy, providing stability despite possible changes of priorities across the years.

The implementation, analysis, and release of results from national and international assessments has been the responsibility of the Educational Quality Agency since 2012. This institution is mandated to conduct assessments and inform the school system and the general public about educational quality. Since its creation, the Agency has communicated information intended to appeal to and mobilize groups with diverse interests. Providing evidence for policymaking is a strategic goal and spreading the results of international assessments in the media is a regular practice. The information is targeted at school communities, policymakers, and academics.

Chile joined the three cycles of the IEA studies in civic and citizenship education-CIVED 1999, ICCS 2009, and ICCS 2016. Currently, it is preparing its participation in ICCS 2022. In this chapter, we review how regular participation of Chile in the IEA civic studies has contributed to the academic and public debate in the country regarding civic and citizenship education (CCE), and consequently, educational policies related to CCE in schools. In order to do so, we first describe how CCE is implemented in the Chilean school system, and comment on the key social

1 Elisa Salinas is part of the European Training Network OCCAM. This project has received funding from the European Union's Horizon 2020 research and innovation program under the Marie Skłodowska-Curie grant no. 765400

2 Both authors were responsible for the implementation of ICCS 2016 in Chile at the International Assessment Unit in the Educational Quality Agency.

3 TIMSS = Trends in International Mathematics and Science Study; CIVED = Civic Education Study; ICCS = International Civic and Citizenship Education Study.

4 PISA = Programme for International Student Assessment.

Gabriela Cares Osorio, Research Division, Education Quality Agency, Santiago, Chile email: gabriela.cares@agenciaeducacion.cl

Elisa Salinas Valdivieso, HIVA - Research Institute for Work and Society, KU Leuven, Leuven, Belgium email: elisa.salinas@kuleuven.be

(C) IEA International Association for the Evaluation of Educational Achievement 2021

B. Malak-Minkiewicz and J. Torney-Purta (eds.), Influences of the IEA Civic and Citizenship Education Studies, https://doi.org/10.1007/978-3-030-71102-3_3 
and political factors that influenced it. Later on, we focus on the relation between the studies and the national curriculum, the CCE assessment in Chile, and relate the current organization of CCE in schools. Next, we describe the role of ICCS in shaping a community of researchers in the country. We conclude with some recommendations for future cycles of the study.

\section{Civic and Citizenship Education in the Chilean School System}

Since 2012, the school system in Chile is governed by the National Education Quality Assurance System. This is an institutional framework consisting of the Ministry of Education, the Educational Quality Agency, the Superintendent of Education, and the National Council of Education. These entities are responsible for defining the national curricular contents, standards of learning, and study programs for each grade. Based on these core guidelines, each school can add further contents and subjects to their study programs. The Ministry of Education is mainly responsible for the administration of the educational policies by providing funding and also official recognition and regulation of schools.

There are 13 years of compulsory schooling in Chile. Current curricular programs are divided into primary school (grade 1-6), lower secondary (grade 7-10), and upper secondary (grade 11-12). Although topics related to CCE have been present in the Chilean school system for more than a century, the subject has experienced many changes in its contents and form. In the last 20 years the evidence created by the participation of Chile in CIVED and ICCS can be mapped onto some of these changes.

As part of significant curricular reform, starting from the mid-1990s, the contents related to CCE were implemented in a cross-curricular way instead of an independent subject. CCE contents were included in the national curriculum in the form of vertical goals (contents related to specific subjects) and transversal goals (cross-curricular contents related to the general school experience). Vertical goals related to CCE can be found mainly in history, geography, and social sciences, although some elements are also present in language and communication, orientation, and philosophy.

The largest curricular reform experienced in Chile in the 1990s was led by the Curriculum and Assessment Division. At that time, both curriculum and evaluation professionals, although separated into different teams, were part of the same unit in the Ministry of Education. Therefore, professionals working on curriculum reforms were very much aware of national and international assessments. Specifically, the updates in the curriculum of civic education were formulated and evaluated by professionals who crucially also worked on the preparation and analysis of CIVED.

The rationale behind moving from a specific subject to a cross-curricular goal was to emphasize the importance of CCE, to recognize its cross-disciplinary nature, and to implement a learning approach based on the promotion of knowledge and also skills. However, the effectiveness of this approach has been seriously questioned in recent years for two reasons. First, there has been no evidence of improvements in the students' results across recurring cycles of CIVED and ICCS. Second, there are indications of low levels of interest in political participation and electoral turnout in recent years.

As a consequence of the cross-curricular approach, there are no specific CCE teachers in the Chilean school system. Those responsible are teachers of history, geography, and social sciences. Currently, the Ministry of Education influences initial teacher training through guiding standards. For teachers in primary education one standard states that teachers are expected to understand the fundamental concepts related to citizenship education, cultural identity, and economic organization. A second requires teachers to develop civic and democratic skills in the students (Ministerio de Educación 2012b). For secondary education, there is one relevant standard stating that teachers are expected to develop teaching strategies to promote civic knowledge, values, and behaviors (Ministerio de Educación 2012a). 
These standards are not mandatory but only guidelines. Mardones (2015) argues that the lack of preparation in contents and didactics results in instructional practices that are heavily influenced by teachers' personal experiences with the topic. A qualitative study conducted by the Education Quality Assurance Agency showed that the level of teacher preparation varies widely. It is not rare to find teachers who are unfamiliar with the contents of CCE included in the curriculum in the subject of history, geography, and social sciences (Agencia de Calidad de la Educación 2016).

Moreover, Mardones (2015) states that there are insufficient regulations regarding teacher preparation; in the current scenario teachers are required to take on a responsibility for which they are not sufficiently prepared. The solution, the author argues, should give more relevance to concepts specific to political science, both in the curriculum and in teachers' initial preparation. This would help achieve a more balanced curriculum than the current one, in which CCE is mainly addressed from a historical point of view. The results from curricular analysis performed by Cox and García (2017) show that key concepts of democratic processes-voting, representation, deliberation, negotiation, and agreements and accountability-have been underrepresented in the Chilean curriculum.

\section{Broad Social and Political Transformations in Chile (1989-2018)}

Some key events that have taken place in the Chilean society during the last several years help to contextualize and better understand the current state of CCE. In this section we analyze a broad political and social panorama, starting from the time of return to democracy to the present, taking as an organizer the different cycles of the international study. ${ }^{5}$

Chile experienced a dictatorship from 1973 until 1989. During this military government, civic education became a curricular subject in 1981. Three years later, civic contents were included in grade 11 , and economics in grade 12. On primary levels, the content related to civic education was addressed in history and social sciences. As part of the transition to democracy, a new curriculum framework was approved in 1996 for primary education, and in 1998 for secondary education. Their implementation processes were gradual, starting with the lowest level of primary in 1997, and the lowest level of secondary in 1999 (Ministerio de Educación 2004). Consequently, the students evaluated in CIVED 1999 were exposed to the pre-reform curriculum.

The political situation in Chile has been transformed during the last 15 to 20 years, with social media and new forms of communication having a central role. The year 2006 represents a milestone in Chile for the future of educational policies and social movements. Hundreds of thousands of secondary students took to the streets demanding a better quality of public education and the repeal of the Constitutional Organic Law of Education, passed during the dictatorial government. The massiveness of the student movement, which received high levels of citizen approval, exerted pressure on the political establishment. The president of the nation in July 2006 ordered the creation of the Presidential Advisory Council of Education. One of its main recommendations was to prepare a new legal framework, and in 2009 a new General Education Law was passed.

The 2006 student movement laid the foundations for a particular style of citizen participation among young people. Street protests and strikes in schools have been regular practices since then. The rise of these new forms of political participation has been accompanied by lower turnout rates and decreased interest in participation in traditional/institutional politics (Castillo et al. 2014; Programa de las Naciones Unidas para el Desarrollo [PNUD] 2009; Treviño et al. 2017). These phenomena are especially obvious among young people, although they are not

5 This chapter was prepared during the first semester of 2019. Starting on October 18, 2019 strong civil protest took place all over the country. They were triggered by the increase in the price of the subway in Santiago but escalated rapidly demanding more equity and stronger social protection regarding pensions, health, and education, among others. Although these events are relevant to the topic here analyzed, their coverage is outside the scope of this chapter. 
exclusive to this group. Several polls show that this disaffection toward political participation is concurrent with a general decrease in trust in institutions (PNUD 2009). Following the revelation of pedophile scandals and economic corruption, citizens' trust has declined in traditionally recognized institutions in Chile like the Catholic Church or the police. Particularly relevant in the political arena were several cases of corruption related to candidates funded by private companies.

The results from the IEA studies on CCE (CIVED 1999, ICCS 2009, and ICCS 2016) have confirmed the existence of several challenges in the preparation of future citizens in Chile. These issues are shared by the other countries of the region that have participated in the study. This is especially evident regarding civic knowledge as the Latin American countries show significantly lower levels of civic knowledge than the international average in every cycle of these studies (Schulz et al. 2010; Schulz et al. 2018; Torney-Purta et al. 2001).

Regarding civic attitudes, in all three rounds of the civic studies there have been questions asking whether certain conditions are good or bad for democracy. For example, whether it is good or bad for democracy when political leaders give government jobs to their family members, or when one company owns all newspapers in a country. In 2009 Chilean students were less likely than the international average to understand that situations such as these pose a threat to democracy (Schulz et al. 2010). Similar patterns appear in 2016 where less than half of the students in the Latin American countries participating in ICCS answered that it was bad for democracy when political leaders give government jobs to their family members, or that one company or the government owns all newspapers in a country (Schulz et al. 2018).

The results of ICCS 2016 show that Chilean students have significantly lower expectations of future political participation than the international average. Moreover, this score for Chilean students in 2016 is significantly lower than in 2009. Interestingly, within every Latin American country participating in ICCS, the group of students reporting that they would certainly participate in national elections are characterized by significantly higher civic knowledge scores than those less likely to participate (Schulz et al. 2010, 2018; Torney-Purta et al. 2001). In summary, the evidence clearly shows that there is room for improvement in CCE in Chile. In the next section we briefly review the use of ICCS for educational policy related purposes.

\section{ICCS's Influence on Chilean Educational Policy}

\section{CCE After the Return to Democracy}

After 17 years of dictatorship, strong citizen motivation accompanied the process of recovering a democratic system. This began with a plebiscite in 1988 that motivated a high turnout. The electorate was clearly interested to vote on the continuity or end of the regime led by Augusto Pinochet. However, a decade later, the rate of young people registered to vote had decreased by half. The return to democracy, the decreasing commitment of young people to participate politically, and the imperative to improve the quality of the educational system were vital arguments that motivated Chile to join the first cycle of the IEA civic study, with preparation for the test and survey beginning in the mid-1990s.

As mentioned earlier, civic education had been included as a cross-curricular area in the educational reform of the 1990s. However, due to gradual implementation, the target population for CIVED had studied under the curriculum implemented during the military government. Consequently, the participation of Chile in this cycle of the study was recognized as a baseline about the knowledge, attitudes, and behaviors of students before civic education reform. ${ }^{6}$ Better results were expected in the next cycle of the study.

6 The interpretation of the results of CIVED as a baseline was presented in the Chilean national report published by the Ministry of Education in 2003. 
In addition to interpreting CIVED results as a baseline to which future results could be compared, the generally poor performance could not be ignored by educational authorities. For both the lower and upper secondary student populations, Chile showed knowledge results significantly below the international average. The situation regarding grade 8 achievement was of particular concern. Among 28 participating educational systems Chile and Colombia obtained the lowest scores.

The Chilean results motivated specialists from the Curriculum and Assessment Division of the Ministry of Education to initiate a critical discussion of the pre-reform curriculum, and present some recommendations for improvement. In 2004, the minister of education called for a Commission on citizen education composed of experts on the subject including representatives of various opinions. The goal for this commission was to propose a well-founded vision of new requirements of education for democratic citizenship, as well as criteria and measures to improve the school experience. The final report prepared by the commission highlights the importance of the IEA international study in influencing the deliberation and proposals of its members (Ministerio de Educación 2005).

The international study was recommended as input and research support for modifications to the curriculum. Among the important issues highlighted by the student results was the poor knowledge of key concepts related to democracy. Neither the Declaration of Human Rights nor the functions of political parties or periodic elections were included in the curriculum between 1980 and 2000. In CIVED, only 16\% of Chilean students answered correctly a question about the function of holding periodic elections; only $32 \%$ of Chilean students answered correctly a question about the duties performed by national legislatures; and, only $34 \%$ understood what violation of civil liberties meant (Torney-Purta and Amadeo 2004).

Based on the data, it was possible to compare the levels of knowledge of grade 8 and 12 students with other countries. CIVED design considered common items administered to both samples allowing for comparison of the results between them (Amadeo et.al. 2002). The size of the difference in the mean tests scores between the grade 8 and grade 12 students in Chile was similar to other countries. ${ }^{7}$ Taking this into account, the recently reformed curriculum was reviewed for its sequence of objectives in civic education, to ensure a more consistent learning progress (Ministerio de Educación 2005). Along with a curriculum with more appropriate coverage of democratic contents and a transversal approach to civic education, pedagogical guidelines and programs were designed to promote opportunities to learn about citizenship in schools.

Contrary to expectations, the results of ICCS 2009 were not significantly better. Chile obtained the highest national average among countries from Latin America and the Caribbean. However, this score was still below the international average and statistically equivalent to the result in CIVED, even though the cohort of grade 8 students of 2004 was educated with the reformed curriculum throughout its entire schooling (Ministerio de Educación 2010).

\section{CCE Assessment in the School System}

During the first two decades after the reestablishment of democracy, IEA's civic and citizenship studies were the only evaluations of the preparation of future citizens in the Chilean schools. In 2012 a law consolidated the national assessment system. This law mandated the creation of Indicators of Educational Quality to supplement the academic national evaluation (named Simce) in building a comprehensive assessment of educational quality.

Eight non-academic indicators were created, four of them are questionnaire-based, administered together with the national academic assessment. These indicators are: academic self-esteem

7 Although the improvement in achievement between grade 8 and 12 can be attributed to teaching and cognitive development, Amadeo et al. (2002) warn that it may also be influenced by the attrition of early school-leavers. 
and academic motivation; school climate; citizenship education and participation; and healthy lifestyle habits. This national policy of non-academic assessment focuses on the promotion of each of these constructs. They are measured annually in grade 4, 6, 8, and 10. According to the law, the results of each school in the academic tests as well as the non-academic indicators are publicly released every year. The assessment results are also considered in the calculation of a high-stakes classification. A repeated poor performance in this classification may imply revocation of official recognition for schools.

The indicator of citizenship education and participation comprises three dimensions: sense of belonging, participation, and democratic participation. It evaluates students' attitudes towards the school, students and parents' perception of how much the school promotes the identification and participation of the different actors of the school community, and students' perception regarding the extent to which the school promotes a democratic life. The assessment frameworks and evidence collected by CIVED and ICCS influenced the decision to include citizenship education and participation as an indicator of educational quality, as well as its definition and operationalization. The indicator has raised awareness of the importance of CCE as an expected outcome of the school system in Chile, and the role of the school in its promotion.

In 2017, a national evaluation of CCE was added to the previously mentioned forms of assessing the subject in the school system. Based on ICCS 2016, this evaluation measured civic knowledge, democratic attitudes and values, and dispositions to participation of grade 8 students. The results of this study show similar patterns to ICCS 2016. In civic knowledge, girls outperform boys and students with higher socioeconomic backgrounds show higher scores. Regarding democratic values and attitudes, students show high level of support for equal rights for minorities but one out of three grade 8 students show attitudes that do not contribute to peaceful resolution of conflicts. Regarding expected political participation, three out of four students mention they will probably vote in presidential elections when they become adults. Girls show higher expectations of political participation than boys.

The national study included a parents' questionnaire. Students whose parents voted in the last election have higher civic knowledge, higher expectations of future political participation, and higher level of support for democracy. A similar pattern is seen comparing students who talk weekly or daily about political and social topics with their parents compared to those that do this less often. These results do not imply that the school lacks relevance for CCE. The school climate, presence of democratic organizations in the school, and classes open to discussion appear as school related factors that are positively associated with civic knowledge as well as with democratic values and attitudes (Agencia de Calidad de la Educación 2018).

\section{Recent Reforms and the Current State of CCE}

In response to the emergence of corruption scandals, the former president Michelle Bachelet called in 2015 for a Presidential Advisory Board to deal with conflicts of interest, influence peddling, and corruption. Giving more relevance to CCE in the school system was one of the measures proposed by the board. More specifically, the creation of Citizenship Education Plans in every school and the inclusion of CCE as an independent subject in the national curriculum was suggested.

A new law mandating the development of more formal recognition of civic education in every school was passed in 2016. The results of ICCS 2009 were mentioned several times during its discussion. It stipulates that based on general guidelines given by the Ministry of Education, every school should design and implement a Citizenship Education Plan coherent with its particular context and oriented to all education levels. These plans consist of activities aiming to prepare students to be responsible citizens, according to the principles of democratic systems and social justice. The program led to a variety of initiatives in the schools: citizenship workshops with a 
multicultural approach, a school municipality that replicates the governance structure of local authorities, or the "World Café," a methodology to discuss environmental challenges. ${ }^{8}$

The inclusion of CCE as an independent subject in the last two years of upper secondary education was approved by the National Council of Education in February 2018 but its implementation was deferred until 2020.

\section{The Use of CIVED/ICCS in Research and Academic Discussions}

ICCS data has been widely used in research, shaping academic discussions around CCE in Chile. ICCS stands out as the only source of quantitative data of students' results in CCE representative of a whole cohort of students in the Chilean school system. While educational researchers in other subjects use the national assessment (Simce) as the main source of information, in CCE this role is played by ICCS. This explains the wide attention that the studies have gained during the past two decades.

The first publication for each of the study cycles has been produced by the governmental institution coordinating the study. The national reports are mainly descriptive and summarize the most relevant results from a national perspective. Building on this evidence, researchers and academics have produced multiple additional publications based on CIVED and ICCS, both in Spanish and English. Most of this research is concentrated in two universities: Universidad Católica de Chile and Universidad Diego Portales. Three main topics can be distinguished in academic research and discussions motivated by CIVED and ICCS results. The first is related to the analysis of the content and format of the national curriculum in CCE; the second is examining to what extent the socioeconomic context is associated with the students' results in CCE; and the third explores school-related aspects that can influence these results. These are briefly discussed in this section.

CIVED and ICCS implementation in Chile have triggered curricular discussions about the most appropriate content, structure, and pedagogical methods for CCE. The assessment frameworks of the studies have influenced the organization of these analyses. The distinction between civic and civil dimensions in CCE is an example of how the assessment framework has contributed by providing a common language for different actors involved. These two concepts have been used in academic publications as well as being key for curricular organization (Bascopé et al. 2015; Cox and García 2017).

IEA's civic and citizenship studies provide empirical evidence which serves as a foundation in the discourse regarding CCE. Two features of the studies have been especially relevant in these discussions. First, the cycles of data collection over time have allowed the assessment of the changes implemented to the curriculum. In fact, ICCS puts into perspective changes in the national curriculum in CCE from the 1990s onwards. Cox and García (2017) analyzed the evolution of the Chilean curriculum in CCE since the return of democracy using three dimensions defined by the ICCS assessment framework. The authors underscore that designing a balance between the civil and civic components of CCE is key to achieving the expected levels of knowledge and civic attitude and values among students.

Second, cross-country comparability is key. Considering the challenges posed by the context of globalization, the country comparisons made possible by ICCS become especially valuable. The participation of several Latin American countries in the study has been particularly relevant for Chile and the region. An important project motivated by ICCS was the SREDECC, ${ }^{9}$ an initiative of

8 The initial implementation of the Citizenship Education Plan was observed through a study conducted by the UNDP and the Ministry of Education. A bank of good practices was built and made available at the website https://www. ciudadaniayescuela.cl/

9 SREDECC = Sistema Regional de Evaluación y Desarrollo de Competencias Ciudadanas (Regional System for the Development and Evaluation of Citizenship Competencies). 
the six Latin American countries participating in ICCS 2009 that promoted further comparative analysis of the regional context, the CCE concepts, and national curriculum of the school systems involved (Cox 2010).

In the context of SREDECC, Cox et al. (2014) developed a comparative analysis of the similarities and differences in the curricular contents of Colombia, Chile, Dominican Republic, Guatemala, México, and Paraguay. The objective was to analyze the functionalities of curricular structures and contents for building democracies in these countries. The findings show that despite the expansion of CCE in themes, skills, and coverage across educational stages, some relevant aspects of political life were given little or no attention. The minimal coverage of concepts focused on citizens and participation were especially of concern; the analysis showed that voting was not explicitly included as part of the curriculum in any of the countries analyzed, except for Mexico. Similarly, participation in political activities was only covered in Guatemala. The authors underscored the low relevance put in the values of common good, social cohesion, and solidarity.

Bascopé et al. (2015) assessed the consistency between the curricular contents and students' attitudes and beliefs across Latin-American participating countries. Using ICCS and SREDECC data they found that curricular contents are associated with students' civic attitudes. Curricular emphasis and students' beliefs regarding five dimensions were contrasted: civic values and principles, citizens and democratic participation, institutions, regional and national identity, peaceful coexistence. The authors find that the Chilean curriculum has a higher emphasis on gender equality compared to the other countries analyzed, and consistently, Chilean students showed the highest level of agreement supporting gender equality in these countries. Based on this evidence, Bascopé et al. (2015) elaborated suggestions to improve national curriculums.

A second issue is the association between the socioeconomic context and students' results in civic knowledge, values, and attitudes. Studies consistently show significant associations between socioeconomic and civic knowledge, at both the individual and school levels (Collado et al. 2015; Schulz et al. 2010; Schulz et al. 2011; Treviño et al. 2016, 2017). Diazgranados and SandovalHernández (2017) based on ICCS 2009 results report the existence of civic socioeconomic gaps in Chile, Colombia, and Mexico which, according to the authors, threaten the legitimacy of democratic systems. Among the three countries analyzed, Chile showed the largest such gap.

Other analyses using ICCS results from Latin-American countries have shown that socioeconomic context is strongly associated with civic attitudes, for example attitudes towards diversity (Diazgranados and Sandoval-Hernández 2017; Treviño et al. 2016). On the other hand, regarding civic engagement, Treviño et al. (2016) find no significant association between expected participation of students and socioeconomic status, although other family characteristics such as parents' interest in political and social issues do predict expected participation. Castillo et al. (2014) report that different indicators of socioeconomic level, such as parent's level of education, number of books at home, and the socioeconomic composition of the school, are strong predictors of students expected political participation. Their analyses also show that the extent to which these family variables explain expected participation increased between 1999 and 2009.

Researchers have also paid special attention to how teachers and schools can influence the student results in CCE and, to some extent, lessen the socioeconomic gap. Research at the international level shows that open climate and classroom contexts can influence students' civic knowledge, values, and attitudes, as well as participation (Knowles et al. 2018). Likewise, it can be argued that teacher characteristics and instructional practices play an important role in promoting democratic environments in the school. Bascopé et al. (2015) underscore the relevance of pedagogical practices in CCE arguing that the ways in which the contents are approached in this subject are especially important. Further, Treviño et al. (2016) argue that this is especially important for Latin American countries due to the high levels of inequalities that characterize the region. This has an impact on egalitarian access to effective political participation. 
Treviño et al. (2017) explored the inequalities in CCE results for Chile, Colombia, and Mexico based on ICCS 2009 results. They found high variance in the level of civic knowledge, civic attitudes, and expected participation within schools, which can be interpreted as evidence that the schools are not fully implementing effective efforts in preparing students for becoming citizens. Nonetheless, democratic environment and an open classroom for discussion are predictors of civic knowledge. Similarly, Castillo et al. (2014) argue that, even though there is space for schools to motivate students' expected political participation by shaping the conceptualization of a good citizen, evidence from CIVED 1999 and ICCS 2009 shows that the socioeconomic composition of the schools and the family characteristics remain powerful.

\section{Conclusions}

The participation of Chile in the IEA civic and citizenship studies has contributed to understanding relevant factors that surround the preparation of future citizens in the school system. Since the first iteration, it has been the primary source of evidence valued by academics and policymakers about CCE in the education system.

The most evident conclusion from the results of the studies is that, despite multiple efforts and a growing concern, there has been no measurable improvement in the general level of civic knowledge of grade 8 students in the Chilean school system across time. Regarding civic attitudes, the increase in the levels of support of equal rights for everyone is positive. Regarding political participation, Chilean students show lower expectations of participation in national elections than the international average. This presents an alarming scenario related to civic preparation that needs to be addressed by the educational system.

Is the school capable of achieving the goal of preparing students to be citizens? Or is this a process that occurs mainly at home? ICCS assessment framework states that the learning outcomes related to CCE occur in a variety of contexts: at home and in the peer environment, at school and in the classroom, and in the wider community. Among them, the school and classroom are recognized as a particularly favorable environment for influencing the acquisition of civic knowledge, attitudes, and values.

The analysis of ICCS data from Chile-as well as from other countries-confirms this. Family characteristics like socioeconomic context or sharing conversations about social and political topics predict civic knowledge. Also classroom and school factors such as an open climate for discussion are associated with higher levels of civic knowledge, and positive attitudes towards minorities. It can be inferred that schools have an important responsibility in shaping the civic knowledge, attitudes, and commitment of future citizens. In contexts of high levels of socioeconomic differentiation, like Chile and Latin America, the role of the school is especially relevant. Schooling presents a key opportunity to counteract the reproduction of social inequalities in access to political rights that characterize this region.

In this context, ICCS's contribution is to provide information on how to improve CCE at school. This information comes from empirical data collected from students, teachers, and schools, but is also derived from academic discussions that are stimulated by the studies. In Chile, this has become evident with the consolidation of clusters of researchers devoted to the analyses of ICCS results during the last years. These groups have made interesting use of the data gathered by IEA studies on CCEE by combining them with national and regional data.

This reflection on the relevance of ICCS for the Chilean school system also sheds light on possible future developments of the study. Bearing in mind the challenge in promoting civic knowledge and attitudes that previous cycles have depicted in Latin America, it would be especially helpful to disentangle the aspects of CCE implementation in schools that are related to students' results. This includes curricular and pedagogical approaches together with teacher characteristics and 
practices. These are aspects that could be modified by educational policies and that have been relevant in other subjects. Exploring whether the same premises are applicable to CCE appears relevant. Are there specific aspects important in the implementation of this subject?

One possible development for the studies would be improving the collection of teacher data. In particular, we suggest to deepen the information collected from teachers regarding their preparation, qualifications, and job conditions on the one hand, and their civic values and attitudes on the other. Also, we believe it would be helpful to allow direct linkage between teachers and students. These modifications would permit greater understanding of the information that teachers provide to their students about citizenship.

A second possibility for development would be to deepen the description of individual and family characteristics of students. This would help in understanding which joint initiatives between the school, the family, and the broader community could be implemented to support CCE. An important question is what kind of support is suitable for the most vulnerable students.

The ICCS assessment framework has been useful constituting a baseline agreement on what different countries and educational systems consider relevant to be taught regarding CCE. An interesting feature of this framework is the balance between stability that allows for trend comparisons, and innovation that allows for the inclusion of new aspects of CCE that become relevant over time. For example, new forms of communication and social participation have been enabled by social media and other technologies; new forms of social tensions have risen due to migration; new forms of political participation and political leadership have appeared thanks to broader access to education; new challenges have been posed to societies by the climate crisis; new moral questions appear with automatization of labor and other spaces of daily life.

It is evident that the citizens of this century require complex skills and knowledge to address emerging challenges. Including these topics in the evaluation of students' learning processes is necessary to understand how school systems might deal with these issues. Using a computerbased assessment would contribute to assessing new aspects of CCE. Computer based assessments open the possibility of having items with interactive stimulus or emulating real-life situations in the context of social media or conducting social research. This format allows more comprehensive measurement of the abilities that this century's citizens need.

\section{References}

Agencia de Calidad de la Educación. (2016). Formación Ciudadana en el sistema escolar chileno: una mirada a las prácticas actuales y recomendaciones de mejora. Santiago, Chile: Author. https://www.agenciaeducacion. cl/wp-content/uploads/2016/02/Estudio_Formacion_ciudadana_en_sistema_escolar_chileno.pdf

Agencia de Calidad de la Educación. (2018). Primer Estudio Nacional Formación Ciudadana. Santiago, Chile: Author. http://archivos.agenciaeducacion.cl/Presentacion_resultados_Estudio_Nacional_Formacion_ Ciudadana.pdf

Amadeo, J.-A., Torney-Purta, J., Lehmann, R., Husfeldt, V., \& Nikolova, R. (2002). Civic knowledge and engagement. An IEA study of upper secondary students in sixteen countries. Amsterdam, the Netherlands: International Association for the Evaluation of Educational Achievement (IEA).

Bascopé, M., Bonhomme, M., Cox, C., Castillo, J. C., \& Miranda, D. (2015). Curricular guidelines and citizenship attitudes in Latin American students: a comparative analysis. Revista Latinoamericana de Ciencias Sociales, Niñez y Juventud, 13(2), 1169-1190. https://doi.org/10.11600/1692715x.13243280814

Castillo, J. C., Miranda, D., Bonhomme, M., Cox, C., \& Bascopé, M. (2014). Social inequality and changes in students' expected political participation in Chile. Education, Citizenship and Social Justice, 9(2), 140-156. https://doi.org/10.1177/1746197914520650

Collado, D., Lomos, C., \& Nicaise, I. (2015). The effects of classroom socioeconomic composition on student's civic knowledge in Chile. School Effectiveness and School Improvement, 26(3), 415-440. https:// doi.org/10.1080/09243453.2014.966725" https://doi.org/10.1080/09243453.2014.966725 
Cox, C. (2010). Informe Regional 2010: Oportunidades de aprendizaje escolar de la ciudadanía en América Latina: currículos comparados. Sistema Regional de Evaluación y Desarrollo de Competencias Ciudadanas (SREDECC), Banco Interamericano de Desarrollo. Bogotá, Colombia: Centro Regional para el Fomento del Libro en América Latina y el Caribe (CERLALC).

Cox, C., Bascopé, M., Castillo, J. C., Miranda, D., \& Bonhomme, M. (2014). Citizenship education in Latin America: priorities of school curricula (IBE working papers on curriculum issues No. 14). Geneva, Switzerland: UNESCO International Bureau of Education (IBE). http://www.ibe.unesco.org/fileadmin/user_upload/ Publications/Working_Papers/education_ciudadana_ibewpci_14_eng.pdf.

Cox, C., \& García, C. (2017). Evolution of citizenship education in Chile. In B. García-Cabrero, A. SandovalHernández, E. Treviño, S. Diazgranados, \& M. G. Pérez (Eds.), Civics and citizenship. Theoretical models and experiences in Latin America. Rotterdam, the Netherlands: Sense.

Diazgranados, S., \& Sandoval-Hernández, A. (2017). The civic competence gaps in Chile, Colombia and Mexico and the factors that account for the civic knowledge gap. In B. García-Cabrero, A. SandovalHernández, E. Treviño, S. Diazgranados, \& M. G. Pérez (Eds.), Civics and citizenship. Theoretical models and experiences in Latin America. Rotterdam, the Netherlands: Sense.

Knowles, R. T., Torney-Purta, J., \& Barber, C. (2018). Enhancing citizenship learning with international comparative research: Analyses of IEA civic education datasets. Citizenship Teaching \& Learning, 13(1), 7-30. https://doi.org/10.1386/ctl.13.1.7_1

Mardones, R. (2015). El paradigma de la educación ciudadana en Chile: una política pública inconclusa. In C. Cox, \& J. C. Castillo (Eds.), Aprendizaje de la ciudadanía. Contextos, experiencias, resultados (pp. 145-173). Santiago, Chile: Ediciones Universidad Católica de Chile.

Ministerio de Educación. (2004). Formación Ciudadana en el currículum de la Reforma. Santiago, Chile: Author.

Ministerio de Educación. (2005). Informe Comisión Formación Ciudadana (Serie Bicentenario). Santiago, Chile: Author.

Ministerio de Educación. (2010). Estudio Internacional de Educación Cívica y Formación Ciudadana ICCS 2009. Primer informe nacional de resultados. Santiago, Chile: Author. https://www.agenciaeducacion.cl/ estudios/estudios-internacionales/iccs/

Ministerio de Educación. (2012a). Estándares orientadores para carreras de pedagogía en educación media. Estándares pedagógicos y disciplinares. Santiago, Chile: Author. https://www.cpeip.cl/wp-content/ uploads/2016/07/libromediafinal.pdf

Ministerio de Educación. (2012b). Estándares orientadores para egresados de carreras de pedagogía en educación básica. Estándares pedagógicos y disciplinarios. Santiago, Chile: Author. https://www.cpeip.cl/ wp-content/uploads/2018/09/Estándares_Básica.pdf

Programa de las Naciones Unidas para el Desarrollo (PNUD). (2009). Informe sobre desarrollo humano para Mercosur 2009-2010. Innovar para incluir: jóvenes y desarrollo humano Informe sobre Desarrollo Humano para Mercosur. New York, NY: Author. https://www.latinamerica.undp.org/content/dam/rblac/ docs/Research

Schulz, W., Ainley, J., Fraillon, J., Kerr, D., \& Losito, B. (2010). ICCS 2009 international report: Civic knowledge, attitudes, and engagement among lower-secondary school students in 38 countries. Amsterdam, the Netherlands: International Association for the Evaluation of Educational Achievement (IEA). https:// www.iea.nl/sites/default/files/2019-04/ICCS_2009_International_Report.pdf

Schulz, W., Ainley, J., Fraillon, J., Losito, B., Agrusti, G., \& Friedman, T. (2018). Becoming citizens in a changing world IEA International Civic and Citizenship Education Study 2016 international report. Cham, Switzerland: Springer. https://doi.org/10.1007/978-3-319-73963-2

Schulz, W., Ainley, J., Friedman, T., \& Lietz, P. (2011). ICCS 2009 Latin American report. Civic knowledge and attitudes among lower-secondary students in six Latin American countries. Amsterdam, the Netherlands: International Association for the Evaluation of Educational Achievement (IEA). https://www.iea.nl/sites/ default/files/2019-04/ICCS_2009_Latin_American_Report.pdf

Torney-Purta, J., \& Amadeo, J. (2004). Strengthening democracy in the Americas through civic education: An empirical analysis highlighting the views of students and teachers. Washington, DC: Organization of American States.

Torney-Purta, J., Lehmann, R., Oswald, H., \& Schulz, W. (2001). Citizenship and education in twenty-eight countries. Civic knowledge and engagement at age fourteen. Amsterdam, the Netherlands: International Association for the Evaluation of Educational Achievement (IEA). https://www.iea.nl/sites/default/ files/2019-04/CIVED_Phase2_Age_Fourteen.pdf 
Treviño, E., Béjares, C., Villalobos, C., \& Naranjo, E. (2016). Influence of teachers and schools on students' civic outcomes in Latin America. The Journal of Educational Research, 110(6), 604-618. https://doi.org/1 0.1080/00220671.2016.1164114

Treviño, E., Béjares, C., Villalobos, C., \& Naranjo, E. (2017). Building citizenship in the schools of Chile, Colombia and Mexico. In B. García-Cabrer, A. Sandoval-Hernández, E. Treviño, S. Diazgranados, \& M. G. Pérez (Eds.), Civics and citizenship. Theoretical models and experiences in Latin America. Rotterdam, the Netherlands: Sense.

Open Access This chapter is licensed under the terms of the Creative Commons Attribution-NonCommercial 4.0 International License (http://creativecommons.org/licenses/by-nc/4.0/), which permits any noncommercial use, sharing, adaptation, distribution and reproduction in any medium or format, as long as you give appropriate credit to the original author(s) and the source, provide a link to the Creative Commons license and indicate if changes were made.

The images or other third party material in this chapter are included in the chapter's Creative Commons license, unless indicated otherwise in a credit line to the material. If material is not included in the chapter's Creative Commons license and your intended use is not permitted by statutory regulation or exceeds the permitted use, you will need to obtain permission directly from the copyright holder. 